\title{
Study On The Performance Of Selected Solar Photovoltaic Systems Installed By Government Intervention Agencies In Delta State, Nigeria.
}

\author{
${ }^{1}$ Agaja, S.A, ${ }^{2}$ Ajibade, B.F, ${ }^{3}$ Nwaezeapu, A.O, ${ }^{4}$ Igbinosun, A \\ ${ }^{1}$ Deputy Director (T), ${ }^{2}$ Assistant Director $(\mathrm{T}),{ }^{3}$ Senior Officer $(\mathrm{T}),{ }^{4}$ Student \\ 1,3,4 Department of Industrial Safety and Environmental Technology \\ ${ }^{2}$ Department of General Studies \\ Petroleum Training Institute, Effurun Delta State, Nigeria.
}

\begin{abstract}
This study evaluated the performance of selected solar photovoltaic (PV) projects installed by Federal and State government intervention agencies in Delta State, Nigeria. Thirty projects were studied, these projects were selected from Delta North, Central and South Senatorial Districts. The data for this study was obtained by using a structured questionnaire and field inspection. The data was statistically analysed using Kruskal-Wallis test at 5\% and two-sample Ttest. The results of the field inspection revealed that the performance of the installed solar PV projects is significantly different $(P>0.05)$ between the two government agencies. There are number of factors that affects solar PV system performance in Delta State, Nigeria, these include; high cost, poor awareness, theft/ insecurity, poor maintenance and lack of technical manpower. Practical steps and measures that can promote better performance (installation, operation and maintenance) of solar PV system as a clean and sustainable source of energy in Delta State are also discussed.
\end{abstract}

Keywords: Environment, Renewable, Sustainable Energy, Solar Photovoltaic (PV) Systems, Green Energy.

\section{INTRODUCTION}

Nigeria is one the largest growing economy in sub-Saharan Africa with a population of approximately 202 million people and one of the largest population of youths in the world. The Nigerian economy growth has been muted since 2015, with economic growth averaged at $1.9 \%$ in 2018 and this remained stable at $2 \%$ in the first half of 2019 [1]. The World Bank report further stated that, the increase in the first half of 2019 can be attributed to the performance in the services sector particularly telecoms. Nonetheless, the manufacturing and production sector recorded a decline and this is as a result of the poor performance in the Nigerian power sector. According to the [2], First Quarter Power Sector Report on Nigeria's Electricity Supply Industry, it is nearly impossible to discuss the growth potential of the Nigerian economy without reference to the challenges in the power sector. The country is endowed with an array of large oil, gas, mineral, hydro and solar resources and has the ability to generate 12,522 megawatts (MW) of electric power from existing hydro-electric and thermal/fossil power plants (Thermal:10,142MW and Hydro:2,380 MW). Unfortunately, in recent times the country has only been able to generate approximately 4,000 MW and this is grossly insufficient [3]

One of the ways the government and stakeholders are increasing citizen's access to electricity, is through the Power Africa Initiative, under auspices of the United States Agency for International Development (USAID) and the U.S. Trade and Development Agency (USTDA). The goal of this partnership is to improve commercial operations and reduce losses of the five national electricity distribution companies: Abuja, Benin, Eko, Ibadan, and Ikeja [3]. Power Africa Initiative is also supporting off grid power projects, with a $\$ 15$ million Overseas Private Investment Corporation (OPIC) loan.

In Nigeria, less than $40 \%$ of the country is connected to the national electric grid, however, less than $6 \%$ of the energy demand of this group is generated or distributed. The Federal Government, through the Federal Ministry of Power and Steel, enacted the Renewable Electricity Policy Guidelines in December, 2006, to drive the renewable energy vision in the power sector, so as, to achieve universal access to affordable, reliable sustainable power [4]. Nonetheless, this initiative can be boosted through an increase in supply of renewable energy to the national electricity supply grid [4].

The country's current energy mix for electricity generation is approximately $70 \%$ thermal and this is mainly originates from coal fired power stations located in various parts of the country and from the unreliable natural gas supply company's [5]. The outstanding $30 \%$ of Nigeria's electricity supply originates from hydro sources, with insignificant contributions from wind and solar technologies [5]. In a study published by the GET. Invest (An African- European Union Renewable Energy Cooperation Programme), the northern and central regions of Nigeria have the potential to generate large amount of electricity from solar PV. The study further stated that the estimated generated capacity for solar PV in both regions (North and Central region) is approximately 43,000MW, and of which a very large portion remains unutilised $[6,5]$.

The Nigerian renewable policy guidelines recognizes only four forms of renewable energy, these are; Solar, Hydropower, biomass and wind. Currently, the total contribution of renewable energy (large hydropower not inclusive) in Nigeria's power industry is approximately 35MW. This comprises of 30MW small hydropower and 5MW solar photovoltaic (PV), this is an abysmal $0.6 \%$ of total nominal electricity generating capacity in Nigeria [4]. Thus, from the aforementioned data, it can be stated that renewable energy 
utilization is still terribly low and the abundant renewable energy potential in Nigeria is still very much untapped. The Federal Government through the Ministry of Power and Steel set the Nigeria's Renewable Energy targets as follows [7,4];

- $18 \%$ electricity from renewables by 2025 .

- $20 \%$ electricity from renewables by 2030 .

- 760 MW small hydro capacity by 2025.

- 400 MW solar PV capacity by 2025.

- $\quad 40$ MW wind capacity by 2025 .

- 5 MW biomass fired capacity by 2015 and 30MW by 2025.

In 2017, the federal government of Nigeria, invested approximately 20 billion US dollars in solar PV projects in various parts of the country and plans are currently ongoing for the development of a 30MW privately owned solar farm which is to be situated in the North eastern region of Nigeria [5]. A basic barrier to the development of solar energy technology in Nigeria lies in high initial costs and long payback times. Nigeria is a developing country and a large majority of the population are poor and therefore, do not have the financial resources to purchase and install these devices thereby resulting in decline in solar energy utilization in the country [8, 9].

The aim of this study is to assess the performance of selected Solar Photovoltaic (PV) systems installed by the State and Federal Government owned intervention agencies in Delta State, Nigeria.

\section{MATERIALS AND METHODOLOGY}

The solar powered projects (street light, traffic light and boreholes) installed by State and Federal government agencies within the last five years in the three senatorial areas of Delta were inspected for efficiency in installation, orientation and maintenance.

\section{Description of study area}

Delta State (Fig. 1) was created in 1991 is located in the southern part of Nigeria. It is an oil and agricultural producing state

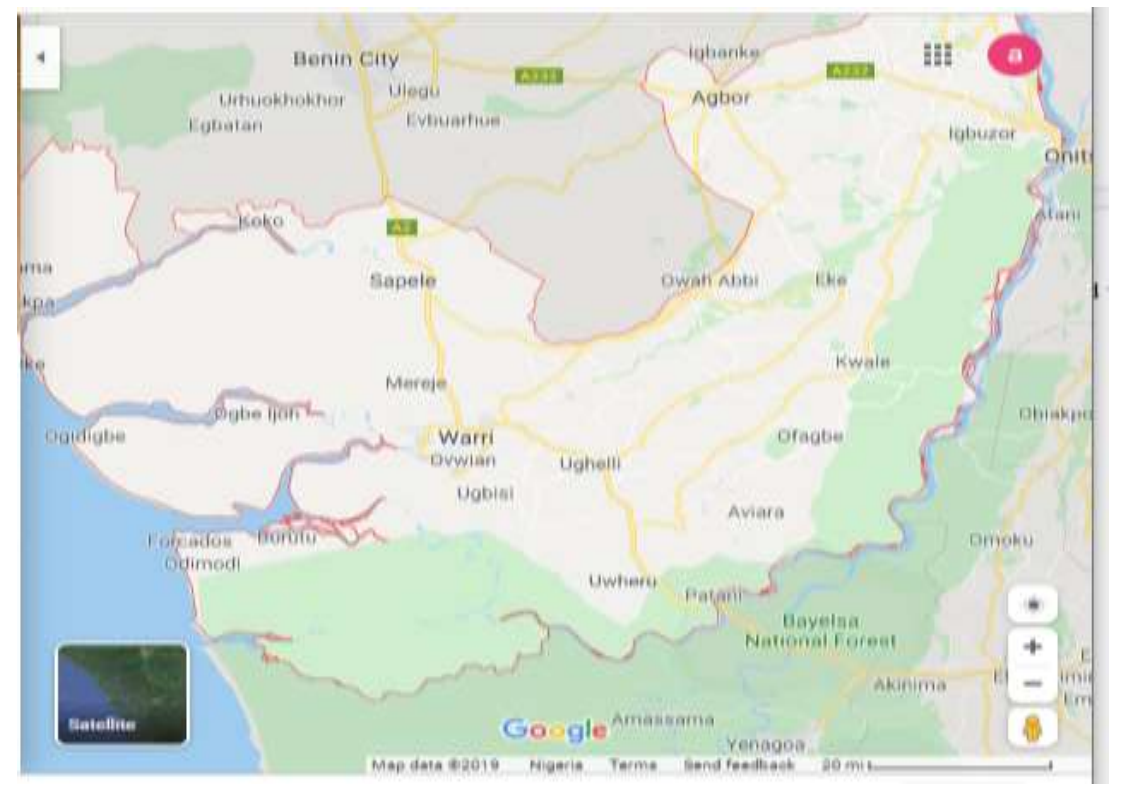

Figure 1: Geographical location of Delta State

Source: Google Maps accessed July 19, 2020

It is situated in the region known as the South-South geo-political zone with a population of 4,112,445.The capital city is Asaba and this is located at the northern end of the state, with an estimated area of 762 square kilometers (294 sq mi), while the city of Warri is the economic center of the state and also the most populated. It is located in the southern end of the state. The state has a total land area of 16,842 square kilometers [10]). Delta State, Nigeria which is an oil and agricultural producing state in Nigeria is still far behind in terms of solar energy utilization. In a report published by the [11], In the years 2016 and 2017, 63.1\% and 50.7\% respectively of the State Gross Domestic Product (GDP) was obtained from non- oil sources. While, 36.9\% and 49.3\% of its GDP was obtained from oil sources. The economic nerve center of the state is the city of Warri and this city used to be the economic hub for oil and gas companies in the Niger Delta Region.

\section{Methodology}

Data collection involved the use of questionnaires, oral interviews and field inspection using a checklist. Oral interviews were conducted on the technical personnel involved in solar powered projects and data were generated based on their response. Questionnaires were also distributed to the engineers working in the Federal and state owned government agencies who are involved 
in installation and maintenance solar powered projects. Similarly, street lights, traffic light and boreholes across Delta State were inspected for efficiency, installation, orientation and maintenance. The data containing the locations of different solar powered projects installed in Delta State was provided by the two (Federal and Stated owned) government intervention agencies.

Similarly, in order, to get a clear understanding of the proper method for installation of a solar PV system, an experimental procedure was set up to simulate a solar PV system placement and orientation. The accessories used to simulate the solar PV system includes; solar panel, charge controller, dial angle gauge and battery. The solar panel was arranged on the ground, mounted on a pole so as to avoid been shaded by tree or building but exposed to the direct rays of the sun. The solar panel was also inclined at an angle as close to the area of latitude as possible to absorb the maximum amount of energy.

The caveat is that the optimum angle which depends on the latitude must be maintained. To determine the optimum angle for solar panel, the latitude of the area was calculated using Global Positioning System (GPS).

\section{RESULTS AND DISCUSSION}

The results of the field inspection of the solar powered projects across the three senatorial districts in Delta State are highlighted in Tables 1, 2 and 3 below;

Table 1:Delta Central Senatorial District

\begin{tabular}{|c|c|c|c|c|c|}
\hline $\mathbf{S} / \mathbf{N}$ & LGA & Location & $\begin{array}{l}\text { Type of Solar } \\
\text { powered project }\end{array}$ & $\begin{array}{l}\text { Working } \\
\text { performance }\end{array}$ & Awardees \\
\hline 1 & Uvwie & $\begin{array}{l}\text { Ugborikoko, DDPA, } \\
\text { Effurun, Agric Road, } \\
\text { Ovie Palace, Effurun. } \\
\text { Warri - Sapele Road }\end{array}$ & $\begin{array}{l}\text { Streetlight } \\
\text { Streetlight } \\
\text { Streetlight } \\
\text { Streetlight } \\
\text { Traffic Light }\end{array}$ & $\begin{array}{l}2 \\
2 \\
1 \\
1 \\
1\end{array}$ & $\begin{array}{l}\text { Federal } \\
\text { Federal } \\
\text { State } \\
\text { Federal } \\
\text { Federal }\end{array}$ \\
\hline 2 & Ethiope West & $\begin{array}{l}\text { Otefe-Oghara, } \\
\text { Mosogar, } \\
\text { Otumare-Oghara }\end{array}$ & $\begin{array}{l}\text { Streetlight } \\
\text { Street light } \\
\text { Streetlight } \\
\end{array}$ & $\begin{array}{l}1 \\
1 \\
1\end{array}$ & $\begin{array}{l}\text { State } \\
\text { Federal } \\
\text { State }\end{array}$ \\
\hline 3 & Ughelli South & $\begin{array}{l}\text { Oginibo, } \\
\text { Usieffurun }\end{array}$ & $\begin{array}{l}\text { Streetlight } \\
\text { Streetlight }\end{array}$ & $\begin{array}{l}1 \\
1\end{array}$ & $\begin{array}{l}\text { State } \\
\text { Federal }\end{array}$ \\
\hline
\end{tabular}

Source: Field Survey, 2020

Table 2: Delta South Senatorial District

\begin{tabular}{|l|l|l|l|l|l|}
\hline S/N & LGA & Location & $\begin{array}{l}\text { Type of Solar } \\
\text { powered project }\end{array}$ & $\begin{array}{l}\text { Working } \\
\text { performance }\end{array}$ & Awardees \\
\hline 1 & Bomadi & Akugbene & Streetlight & 1 & Federal \\
\hline 2 & Burutu & Burutu Town Oboro & $\begin{array}{l}\text { Streetlight } \\
\text { Streetlight }\end{array}$ & 1 & $\begin{array}{l}\text { Federal } \\
\text { State }\end{array}$ \\
\hline 3 & Warri South & Okpe-Isoko & Streetlight & 4 & Federal \\
\hline 4 & Isoko South & Oleh & Streetlight & 1 & Federal \\
& & Oleh Campus & Streetlight & 2 & Federal \\
& & Atebo & Streetlight & 1 & State \\
\hline 5 & Isoko & Okpe-Isoko & Streetlight & 1 & State \\
& & Emevo & Streetlight & 2 & Federal \\
\hline
\end{tabular}

Source: Field Survey, 2020

Table 3: Delta North Senatorial District

\begin{tabular}{llllll}
\hline S/N & LGA & Location & $\begin{array}{l}\text { Type of Solar } \\
\text { powered project }\end{array}$ & $\begin{array}{l}\text { Working } \\
\text { performance }\end{array}$ & Awardees \\
\hline 1 & Ndokwa West & Utagbi-Uno Agiliame & Streetlight & 3 & Federal \\
& & & Streetlight & 1 & Federal \\
2 & Ndokwa East & Obi-Obeti Afure & Borehole & 1 & State \\
& & Obodigbo & Borehole & 3 & State \\
3 & Aniocha North & Akoku & Borehole & 1 & State \\
\hline
\end{tabular}

Source: Field Survey, 2020 
Key for working performance

\begin{tabular}{|l|l|}
\hline Rating options & Description \\
\hline 1= Poor & Bad, Not working, faulty; Maintenance and replacement of damaged parts required \\
\hline 2=Average & Satisfactory working performance. Regular Maintenance required \\
\hline $3=$ Good & A consistently high standard of performance. On scheduled Maintenance \\
\hline $4=$ Very Good & Excellent standard of performance. On scheduled Maintenance \\
\hline
\end{tabular}

Table 1 shows that out of the ten solar powered project that was inspected in Delta Central Senatorial District from three Local Government Areas and only two was in good working performance, while eight were in a bad condition may be attributed to poor maintenance. The batteries are placed on ground level where it is exposed to theft and climatic/environmental conditions. Furthermore, the solar panels were installed with no consideration of the tilt angle of the latitude of the area and lastly, the electrical conductors are not neatly and professionally held in place.

Table 2 revealed that ten solar powered projects were inspected in Delta South Senatorial district. Eleven projects were inspected, in five Local Government Areas. The results showed that, four of these projects inspected had a good working performance. However, one was working more effectively than the others. The remaining six projects had poor working performance and this may the attributed to poor maintenance, the electric boxes are not accessible, poor electrical connection and lastly, the array of electrical conductors and fittings are not professionally held in place.

Table 3 shows that five solar powered projects were inspected in Delta North Senatorial District. Out of the five, only two were in good working condition while the performance of the other three installed projects was poor. It was also noticed that the batteries were placed on ground level and no maintenance work has been carried out since its installation.

\section{Comparison of solar PV performance in the three locations}

The Data collected from three senatorial areas in Delta state was analysed using Kruskal-Wallis test at 5\%. This was carried out to determine if there is significance variation in the performance of PV solar systems installed in the three locations irrespective of installer (state or federal).The result revealed that the $\mathrm{P}$-value of the test is greater than $0.05(\mathrm{P}>0.05)$ which implies the performance does not significantly vary among the locations irrespective of installer (State or Federal).

\section{Comparison between the two government agencies}

The data was also analyzed using a two sample t-test to determine whether there is a significant variation in the performance of solar PV systems installed by the two government agencies (State and Federal). The P-value of the test is less than $0.05(\mathrm{P}<0.05)$ which implies the performance is not the same for the two government agencies. From the mean value, the mean rating of the State installed solar PV projects is less than that of Federal which implies that the variation in the rating is statistically significant $(\mathrm{P}<0.05)$.

\section{DISCUSSION OF RESULTS}

There are several factors that can cause the solar PV system installed by one agency to perform better than the other thus, impeding the performance of solar PV system in Delta State, Nigeria. The results from the statistical analysis of the field inspection revealed that the solar PV systems installed by the Federal government intervention agency performed better than the state government installed projects. This may be attributed to a number of factors such as; high budget allocation for installation and maintenance of solar PV projects, availability of technical personnel and Good quality of products. Studies has shown that there are number of factors that affect solar energy performance in Nigeria. They are; High cost, lack of awareness, insecurity, poor maintenance and lack of technical manpower $[12,9,8]$.

\section{Problems Associated With Solar PV Systems in Delta State}

There are a number of problems associated with solar PV performance in Delta State, Nigeria. These are as follows;

\section{Cost of purchase, installation and maintenance}

Cost is a major drawback to solar energy utilization in Delta state. In Nigeria the use of renewable energy particularly solar energy for power generation is still the early stage of development. The components/parts of the solar PV system which are imported from overseas enter the country through the sea ports which are controlled by the federal government, Nigeria and indeed Delta State is still underdeveloped with a higher percentage of her population living under poverty level. This makes the ability to acquire solar energy devices difficult. The Federal government have the resources and power for trade/bilateral agreements with the solar manufacturing countries thereby sourcing original components and importing these solar PV systems at a reduced cost thus, reducing the cost of purchase.

However, the case may be different for the state owned agencies, which is heavily dependent on Federal government allocation to fund part of its budget and projects. Similarly, they do not have the available resources to offer trade agreements with the manufacturer 
of the solar PV systems and they have to use contractors to source this components and this is usually done at a higher price (possibility even a lower quality) from suppliers across country. [13] agreed that high cost of solar PV systems is a main barrier to the adoption of solar PV systems in Akure, Ondo, state. The paper also highlighted other barriers such as; lack of awareness, environmental conditions and lack of technical knowledge as hindrances to growth and development of solar PV systems in Akure, Ondo State.

\section{Poor quality of products}

The performance of the solar PV systems installed by State and Federal may vary significantly due to the quality of the installed solar PV system/components. The Federal government have a vast supply of resources to directly source the solar PV components from the manufacturers, by this means, installing standard PV systems with a longer lifespan. Nevertheless, the case may be different for the state owned agencies who do not have the available resources (primarily due to low budget allocation for power/renewable energy) to source products directly from the manufacturer.

Subsequently, they have to use local contractors to source the solar PV components from local suppliers and these components may be of a lower standard/quality. This is supported by findings of [14] who stated that, there are no effective government standards or specific requirements monitoring /regulating the quality/grade of solar PV products that should be imported into the country. The solar PV market is flooded with substandard products some of which have no brand name or warranty and when these products are installed they shorten the life span of the solar PV system thereby causing residents/users to be dissatisfied with the quality of service rendered either by the federal or state government intervention agencies [9].

\section{Technical Personnel}

Another factor that affects the performance of the solar PV system is level of technical knowledge of the project team. Renewable energy is a fairly new energy concept in Delta state and Nigeria as a whole and as a result, most electrical engineers are focused on design and installation of electricity in homes, businesses and oil installations and as such the state agencies do not have access to a vast team of skilled personnel's who have the ability to quickly detect any failure or improper installation before major damage is done. Most of the technical staff of the state agency are indigenes of the host communities in the state and are imposed on the state government and as such, they do not have the adequate skills, and knowledge and expertise perform their job effectively.

On the contrary, technical personnel's from the federal intervention agencies are made up of people from the different parts of the country who are carefully selected through rigorous examination /interviews process and thus possess the right skills and expertise to properly install and supervise solar PV projects.This is finding is in agreement with [12] who studied the challenges facing solar energy projects in Nigeria. The study pointed out that the lack of skilled technical knowledge is one major causes of failure in solar PV projects in Lagos state and proposed that a solar project engineer, someone with in depth knowledge on renewable/solar PV systems, installation, operation and maintenance should supervise solar powered projects. Similarly, this finding is also in tandem with [4] study on renewable energy development in Nigeria, which pointed out that the renewable energy market do not have a large number of skilled personnel who can install, operate, maintain solar energy systems.

\section{Poor, installation and maintenance}

This is another factor that affects the performance of solar PV systems installed by both federal and state agencies. Solar energy utilization, is still in the early stages of development in Nigeria and there is shortage of manpower and skills to operate and maintain the solar PV systems. This is scenario is more severe for the state owned government intervention agencies whose technical personnel's are mainly made of host indigenes and thus do not possess adequate skills and expertise to install, and maintain the solar energy systems.

This finding is in agreement with [12] study which stated that, one of the factors causing the failure of installed solar PV projects is poor maintenance. This can be linked to shortage of trained personnel and as such when the trained personnel are available, they are often too busy to monitor installation, operation and maintenance of the solar projects and this shortens the life span of the commissioned project. Furthermore, [14] also suggest that the absence of skilled technical support for the installation, operation and maintenance of solar projects may slow down the development of solar powered projects especially in rural areas.

\section{High illiteracy rates}

According to the [15], over 41 million Nigerians aged between 15 years and are illiterate. This means that in Nigeria, there is low level awareness on the enormous socio-economic and environmental benefits derivable from solar energy [8].The current trends of information concerning the development, various applications, dissemination and diffusion of solar energy resource and technologies are grossly inadequate and should be stepped up through various channels such as; social media, networks, schools etc.

\section{Lack of effective national energy policy}

The Federal government of Nigeria through its relevant agencies have set up policies to promote and harness/develop the renewable energy potential of the country. According to [16], there are three main renewable energy generation policies in Nigeria and they are as follows; Nigeria Feed-on Tariff for Renewable Energy and Sourced Electricity (RNSE), Multi-Year Tariff Order (MYTO) and Nigeria Renewable Energy Master Plan (NREMP). The installed capacity target which was set up by NREMP, is proposing an increase in small hydro power by 1400MW in 2025, increase in Solar PV systems to 500MW, wind energy to 40 MW and biomass powered plants by 385MW. The RNSE policy stipulates that, electricity distribution companies should purchase $50 \%$ of electricity 
from renewable sources and the MTYO II ensures the renewable energy tariffs are fixed and proportionate to market price of conventional energy sources [16].

Nevertheless, due to government bureaucracies, such policies are not actualized and never see the light of day and they mostly end up at the back pages of newspaper publications, ministry/parastatals newsletters or form part of a keynote /welcome address for government functionaries in conferences and seminars $[14,16]$. On the contrary, Government support in form of subsidies are usually given to investors of conventional energy to boost energy supply in the country however, this creates an unfavorable and competitive environment for solar energy to grow in Nigeria [16] In a study carried out by [17], the paper highlighted that, lack of awareness and politics, as the two major challenges affecting the growth and development of solar energy in Nigeria. These factors have negatively contributed to the poor implementation and monitoring of renewable energy policies and targets.

\section{Insecurity and Vandalism}

There is high rate of poverty and unemployment in the State and, as a result, the solar PV systems are prone to theft and vandalism. Most times, some of these stolen components are employed for their personal use while others are resold to solar PV dealers or end users at a reduced price. Similarly, insecurity also arises through the incessant kidnap of key project personnel's during routine site inspection or installation activities. Thus, resulting in the delay in project completion, inspection or monitoring and this ultimately reduces the performance of the performance of the solar PV system. [9] agrees that theft and vandalisation is one of the principal challenges facing the utilization of solar energy in Nigeria. Furthermore, [14], agreed that the general state of insecurity around solar installations around the country through the killing and abduction of workers in various parts of the country can threaten the growth and development of large scale solar PV systems in Nigeria.

\section{CONCLUDING REMARKS}

In this paper, the performance of selected solar photovoltaic systems installed by government intervention agencies in Delta State, Nigeria was investigated. The solar PV systems installed by Federal governments agencies performed better than those installed by State owned intervention agencies. The poor performance of solar photovoltaic systems installed by state owned agencies in Delta State can be linked to low budget allocation for renewable energy, lack of technical manpower, poor quality of solar PV system components and poor maintenance. Nevertheless, it would be irrational to say that these aforementioned underlining factors are only limited to state owned intervention agencies. There are other factors such as; inadequate training, theft and vandalism, lack of awareness, technology of equipment and fabrication, environmental as well as climatic conditions that can greatly affect the performance of solar PV systems regardless of whether it was installed by a Federal government, State government or private/corporate entity. Therefore, in order to extensively improve the performance of Solar PV systems in the State, vigorous and enforceable policies should be established and duly maintained. These policies should be backed with strong political influence at both Federal, State and Local government level. These laws/policies are duly essential to promote the actualisation of the following recommendations needed for the performance improvement of solar photovoltaic systems in the State.

\section{Recommendations}

- Proper follow-up on the maintenance of solar photovoltaic system e.g. exchange of the battery when it has reached its end of life, cleaning of the panel surface to remove dust and dirty which create a layer on the panel surface, thereby, preventing direct penetration of sunlight with the panel.

- Private/corporate body involvement in solar PV projects should be encouraged.

- Batteries of a PV system should be properly installed in a manner, so as, to avoid theft and vandalism.

- More research should be made on the design and fabrication of solar PV systems using locally sourced materials so as to reduce the cost of importation.

- $\quad$ Proper awareness and publicity should be carried out on the benefits of renewable energy in the country.

- Proper training and certification of technical staff on the proper method of installation, operation and maintenance of soar PV systems.

- Solar panel should be placed where it can get optimum sunlight from the sun in other for it to work in a good capacity.

- Agencies should consider the use of all in one solar street light which are popular in wide open area and in places rich in sunlight and lack constant power supply. The system integrates the solar panel, Light-emitting Diode (LED) lamp, LED source, die casting cap, Passive Infrared Sensor (PIR) motion sensor and lithium battery into to one single product. There are no arrays of electrical wires or heavy batteries to carry thus making it very practical and convenient. This ultimately reduces the cases of poor installation, missing component, theft and vandalism and environmental factors. It also makes maintenance activities easy and less cumbersome

\section{ACKNOWLEDGMENT}

The researchers acknowledge the support rendered by the staff of Federal and State owned government intervention agencies in Delta State, Nigeria. 


\section{REFERENCES}

[1] World Bank. (2019). This is what it's all about. Boosting renewable energy in Africa. Retrieved October 17, 2019 from https://www.worldbank.org/en/news/feature/2019/02/26/this-is-what-its-all-about-boosting-renewable-energy-in-africa.

[2] KPMG. (2019). Nigeria's Electricity Supply Industry Highlights. Power Sector Watch. Edition 2019-Q1. Retrieved October 17, 2019, from https://assets.kpmg/content/dam/kpmg/ng/pdf/audit/Nigeria-Electricity-Supply.pdf

[3] United States Agency for International Development. (2019). Nigeria Power Africa Fact Sheet. Retrieved October 17, 2019, from https://www.usaid.gov/powerafrica/nigeria

[4] Awogbemi, O. and Asaolu, J. I. (2014). Towards renewable energy in Nigeria. Elixir Mechanical Engineering Journal 72(2014), pp. 25320-25323

[5] Adewuyi, O.B ., Kiptoo, M.K., Afolayan, A.F., Amara, T., Alawode, O.I., and Senjyu, T. (2020). Challenges and prospects of Nigeria's sustainable energy transition with lessons from other countries' experiences. Energy Reports. 6 (2020) 9931009

[6] Get. Invest. (2015). Nigeria: Renewable Energy Potential. Retrieved August 6, 2020 from https://www.get-invest.eu/aboutrecp/

[7] Zumunta, M.D. (2013). "Financing for a Renewable Energy Market in Nigeria". Paper delivered at the Lagos State Climate Change Summit. Pp 4, 16

[8] Oji, J.O., Idusuyi, N., Aliu, T.O., Petinrin, M.O., Odejobi, O.A. and Adetunji, A.R. (2012). Utilization of Solar Energy for Power Generation in Nigeria. International Journal of Energy Engineering 2(2), pp.54-59

[9] Akinboro, F.G., Adejumobi, L.A. and Makinde, V. (2012). Solar energy installation in Nigeria: observations, prospect, problems and solution. Transnational Journal of Science and Technology. 2(4), pp. 73-84

[10] Delta State Government, (2019). Welcome to Delta State. Retrieved March 12, 2020, from https://www.deltastate.gov.ng/

[11] Nigeria Bureau of Statistics (2020). NBS E-library: States Nominal Gross Domestic Product. Retrieved February 18, 2020, from https://nigerianstat.gov.ng/elibrary?queries[search]=GDP

[12] Adeyemo, H. (2013). Challenges facing solar energy projects in Nigeria; A case study of Lagos state. (Masters thesis, HAMK University of Applied Science, Vankanlähde, Finland). Retrieved from, https://www.researchgate.net/publication/274388724_Challenges_facing_solar_energy_projects_in_Nigeria_A_case_stud y_of_Lagos_state

[13] Saka, A.B, Olawumi, T.O. and Omoboye, A.J. (2017). Solar Photovoltaic System: A Case Study of Akure, Nigeria. World Scientific News 83 (2017), 15-28

[14] Ohunakin,O.S., Adaramola, M.S., Oyewola, O.M. and Fagbenle R, O. (2014). Solar energy applications and development in Nigeria: Drivers and barriers. Renewable and Sustainable Energy Reviews 32(2014) 294-301

[15] United Nations Educational Scientific and Cultural Organization. (2015). Education and literacy report. Retrieved October 17, 2019 from http://uis.unesco.org/country/NG

[16] Wole-Osho, I., Bamisile,O., Adun, H. and Yusuf, I. (2016). Comparison of renewable energy potential in relation to renewable energy policy in ECOWAS Countries. Paper presented at HONET-ICT Conference Proceedings, Nicosia, Cyprus. Retrieved from https://doi: 10.1109/HONET.2016.7753441

[17] Bamisile, O., Dagbasi, M., Babatunde, A. and Ayodele, O. (2017). A review of renewable energy potential in Nigeria; solar power development over the years. Engineering and Applied Science Research 44(4):242-248. 